\section{Silicon manufacture \\ Monsanto sets up in Britain \\ THE United States chemicals group} Monsanto last week announced plans for a $\mathrm{f65}$ million investment in a new British silicon wafer research and production operation. The intention is further to improve crystal purity, which will involve developing new instrumentation, and eventually to manufacture wafers of up to 8 inch $(200 \mathrm{~mm})$ diameter. Monsanto expects to collaborate extensively with British university departments. World supplies of silicon wafers manufactured to the required purity and high degree of flatness are at present restricted to relatively few manufacturers. Demand is expected to increase rapidly, however. Monsanto is a leading supplier to the semiconductor industry in the United States but lags in Europe. The new Monsanto facility will be at Milton Keynes, a new development town in central England. The company explains that it was looking for a green-field site, which Milton Keynes possesses in abundance, and that Britain was chosen from a short-list of eight European countries. The British Government has helped with grant assistance, although the amount is not being made public.

In declaring its intention to move towards 200-mm wafers, Monsanto seems to be making the point that it wants to keep two steps ahead of the competition: else- where, $150 \mathrm{~mm}$ is proving difficult. Monsanto boasts leadership in producing $125-\mathrm{mm}$ wafers in a peak-to-valley flatness of less than 2 micrometres. But as modern wafer-stepping semiconductor manufacturing techniques become more widespread, edge-to-edge flatness will cease to be a major constraint. Local slope and crystal purity may become the limiting factors to cramming semiconductor devices onto wafers.

Two trends are combining to make purity a problem. First, chips are becoming larger, so that there is a decreased chance that each chip will be flawless. Second, channel widths are now moving down to the order of micrometres so even very small local deformities in crystal structure can disrupt a device. Implanted ions tend to spread from their original deposition sites during the manufacturing process, for which allowance has to be made in the design. The extent of the spread is determined by the structure and purity of the original lightly-doped crystal, and this is where the thrust of the research effort is likely to be. Initially, Monsanto will import wafers from the United States for cleaning and polishing in Britain, but will later embark on crystal manufacture, hoping eventually to supply 50 per cent of the British silicon market.

\title{
Research councils defend manning
}

SIR Hermann Bondi, chairman of the Natural Environment Research Council (NERC), appeared before the Public Accounts Committee of the House of Commons on 14 May to give a doughty defence of his council's manpower planning. The National Audit Office recently criticized research councils and the Department of Education and Science for apparent laxity in their planning controls (see Nature 309, 104; 1984), and suggested that there had been an unexplained upward drift of salary grades at councils including NERC. But, according to Sir Hermann, the increase in the number of senior posts was a planned development and a completely appropriate outcome of the changing role of NERC.

Sir Hermann said that over the past 10-15 years the need for lower-grade NERC staff on foreign aid programmes had decreased, as local inhabitants had been trained to take over their jobs. The simple result was that the staff NERC retained were now in higher grades. He also asserted that NERC institutes such as the Institute for Marine Environmental Research were deliberately established with young scientists who would $\operatorname{climb}$ up the ladder of promotion.

Sir Hermann also pointed out that scientific equipment had become more complicated, so that many measurements that

were formerly made manually are now made by computer. This also led to a smaller requirement for lower-grade support staff.

He went on in stirring style to turn the tables on MPs who had been led to doubt whether the research councils were discharging their manpower planning duties effectively. The main charge of the $\mathrm{Na}$ tional Audit Office was that the research councils had not been keeping their staff grades in line with those in the civil service. The Public Accounts Committee was particularly worried about "fluid grading" of science research posts. Sir Hermann's ingenious reply was that manpower planning in NERC is better than that in the civil service. The in-house system of visiting groups, promotion boards and annual reviews was all that could be desired.

The committee's next witness, Dr Ralph Riley, secretary of the Agricultural and Food Research Council, said that the controls on manpower in his council were similar to those at NERC, so much the same arguments applied.

The committee appeared well pleased with these answers. But research councils have not escaped completely unscathed. Mr David Hancock, permanent secretary at the Department of Education and Science, used the occasion to announce a "thorough review" of fluid grading.
Tim Beardsley
US high-technology investment Partnerships
lose shine

\section{Washington}

THE downturn in high-technology stock prices is hampering efforts by biotechnology companies to raise research and development funds through other routes as well. Last week, Biogen revealed that it has raised only $\$ 25$ million of the $\$ 40$ million it had been counting on for a research and development partnership to finance the company's commercial development of gamma-interferon and interleukin-2. In recent weeks, other biotechnology research and development partnerships have met with a similar reception from investors. Hybritech was able to raise only half of the $\$ 80$ million it was aiming for; and Centecor, which had hoped to raise \$10-\$15 million, now says it will be happy with $\$ 5$ million.

Research and development partnerships are attractive to companies because they can provide stable support for long-term research and because they are a source of capital which does not dilute the equity holding of existing shareholders. Private investors obtain immediate tax benefits and later receive a share of the royalties from any inventions arising from the research. The partnerships are especially useful to emerging industries such as biotechnology which do not yet have products on the market and thus do not have a reliable source of revenue. They also give the companies far greater freedom than they would have if they entered into agreements with a single corporate research sponsor.

In the Biogen offering, the company ended up putting $\$ 35$ million of its own money into the research and development partnership, considerably more than the $\$ 20$ million it had planned.

The lack of enthusiasm for the partnerships reflects several developments. Biotechnology stocks have not been doing well on the market lately. What is more, several limited research and development partnerships in the computer field have recently received unfavourable attention for their failure to produce commercial products, which has tended to give all hightechnology ventures a bad name. The most prominent case was that of Storage Technology, which raised close to $\$ 100$ million for a research and development partnership that was to produce a mainframe computer to compete with that of IBM.

Nelson Schneider of E.F. Hutton says that another factor behind the poor reception for research and development partnerships in biotechnology is that there is now much more competition for the investors' dollars. "There are literally dozens out there in the market in the $\$ 2-10$ million range in biotechnology", he says.

Stephen Budiansky 